\title{
GROWTH AND YIELD OF FOUR INDONESIAN IMPROVED SOYBEAN VARIETIES BASED ON BIO-DETAS INPUT PACKAGE IN RAINFED LOWLAND OF CENTRAL LOMBOK
}

\author{
Nani Herawati*, Ai Rosah Aisah, and Baiq Nurul Hidayah \\ Institute for Assessment of Agricultural Technology (Balai Pengkajian Teknologi Pertanian) West \\ Nusa Tenggara Province, Jalan Raya Peninjauan Narmada, Lombok Barat, Nusa Tenggara Barat \\ 83371 Indonesia \\ *Corresponding author: baiqnurul@pertanian.go.id
}

\begin{abstract}
Soybean is one of the most important food crops in Indonesia after rice and corn, due to its protein content reaches $40 \%$. Rainfed lowland can be used as expansion planting area in hopes of obtaining high productivity with efficient inputs. In order to increase yield, it is necessary to apply the Bio-Detas input package that priorities the use of adaptive improved varieties, organic fertilizers and biological pesticides. This research aim to investigate the response of four Indonesian improved soybean varieties based on the application of Bio-Detas input package in rainfed lowland. The experiment was conducted from March to July 2018 in Pengembur Village, Central Lombok Regency of West Nusa Tenggara Province, Indonesia. The experiment was conducted using a non-factorial randomized block design with varieties as treatments, namely Argomulyo, Burangrang, Dega-1, and Dena-1. Each treatment was repeated three times therefore there were 12 experimental plots in total. Parameters observed during the vegetative and generative phases including plant height, number of branches, number of leaves, number of nodus, number of flowers and number of pods. Data were collected from five plants for each replication. Results showed that varieties had a significant influence on the number of leaves, number of nodus and number of flowers during the vegetative phase. While during the generative phase there were a significant effect of varieties on plant height, number of leaves and number of nodus. Due to dry season occurred earlier in April, yield on Bio-Detas input package was reached $578 \mathrm{~kg} / \mathrm{ha}$ compared to farmer's existing technology was $393 \mathrm{~kg} / \mathrm{ha}$.
\end{abstract}

Keywords: bio-detas input package, rainfed lowland, soybean varieties

\section{INTRODUCTION}

Soybean (Glycine max L.) is one of the potential food sources of Indonesian society. This is caused by a protein content that reaches $40 \%$. Soybean contains high protein and become a raw material for various processed foods such as tofu, tempeh, soy milk, soy sauce, and bean sprouts. Soybean production with demand for this commodity increase year by year cannot be fulfilled by domestic production therefore the fulfillment of soybean needs is done through importation. The main obstacle of soybean production in Indonesia is low productivity. Indonesian soybean production in 2017 was 539,000 tons with a productivity 
of 1.5 tons/ha (Kementerian Pertanian, 2019). This value is still lower when compared to soybean requirements for January to August 2018, which was $1,985,800$ tons (Kementerian Perdagangan, 2018). Meanwhile, some governmental efforts to increase soybean production include increasing planting area, use of new improved varieties as well as use of certified seeds (Kementerian Pertanian, 2018).

Soybean can be grown in rice fields or dry land and do not require a lot of water. Soybean planting in rice fields is generally conducted in the dry season (DS) I and II, and on dry land in the rainy season (RS) (Zakaria, 2010). Growth and development of soybean through two phases, namely the vegetative and generative phases. In the vegetative phase the growth is slow but after entering the generative phase the soybean growth is much higher. However, all depends on the light conditions that affect growth as well as other components such as fertilizers that are influenced (Basuchaudhuri, 2016).

One effort to increase soybean productivity is expanding of planting area into suboptimal land, such as dry land and rainfed land. The Ministry of Agriculture Republic of Indonesia is continues to expand soybean planting areas and increase productivity. Rainfed land is the land that relies on water sources from rainfall. Generally on rainfed land in Lombok Island, farmers plant rice once a year followed by other crops such as maize or soybean. Soybean productivity in rainfed land is low based on research conducted by Herawati et al. (2018) on rainfed land in Central Lombok District, soybean farmers who planted soybeans in the existing way gained a yield of $0.7-1.0$ ton/ha. This is caused by high evaporation rates, low soil water content and low soil fertility due to lack of water in the land (Lenin et al. 2015).

$$
\text { West Nusa Tenggara }
$$

(WNT)

Province has a fairly extensive rainfed land after irrigated rice fields. The rainfed land based on statistical bureau data for 2017 is 64,207 ha. With details of the highest in District of Bima (16,299 ha), then followed by Sumbawa and Central Lombok Districts, 15,722 ha and 13,515 ha respectively (Biro Pusat Statistik, 2018).

In an effort to gain high productivity with efficient inputs, it is necessary to apply the Bio-Detas input package that emphasizes the use of adaptive improved varieties, biological/organic fertilizers, and biological pesticides. Therefore, the package needs to be applied on new improved varieties of soybeans in order to determine the response of each variety towards the application of Bio-Detas input packages. The objective of this research was to investigate the response of four Indonesian improved soybean varieties based on the application of Bio- 
Detas input package in rainfed lowland of Central Lombok Regency.

\section{MATERIALS AND METHODS}

\section{Materials}

The materials used in the field were improved soybean seeds from Indonesian Legumes and Tuber Crops Research Institute (ILETRI) Malang, Indonesia namely Argomulyo, Burangrang, Dena 1, and Dega 1 varieties; fertilizer (NPK Phonska, SP-36 and Petroganik biofertilizer); and pesticides (herbicide and bio-insecticides). The use of those four varieties because Bio-Detas input package required new improved and adaptive varieties in order to optimize yield and those varieties were available during that growing season. Experiments in the field used the following tools: cow plows, hoes, sprayers, raffia ropes, ruler, cameras, hand counters, plastic bags, tarps, analytical scales, stationery and laboratory equipment for soil analysis and plant nutrient analysis.

\section{Methods}

The study was conducted in the dry season I (DS I) on rainfed lowland, starting from March to July 2018, located in Pengembur Village, Central Lombok Regency. The experimental was using a nonfactorial randomized block design, consisting of the treatment of four soybean varieties namely Argomulyo, Burangrang, Dena 1, and Dega 1. There are three replicates for each variety; therefore there were 12 experiment plots in total.

Land preparation was without tillage. Rice straws from previous harvest were cut 1-3 cm above the surface of the soil, weeds were sprayed using herbicide with dose of 23 liters/ha, then drainage channels were made at each bed width of 4-5 m. Experimental plots were made with a size of $5 \mathrm{~m} \mathrm{x} 7 \mathrm{~m}$.

Viability of soybean seeds before planting were $>80 \%$. Seeds were mixed with Agrisoy bio-fertilizers using a dose of 40 grams $/ 8 \mathrm{~kg}$ of seeds. Agrisoy is a rhizobium inoculum that is able to stimulate the formation of root nodules, and more than $60 \%$ of the plant's $\mathrm{N}$ fertilizer requirements can be met by the plants themselves through nitrogen fixation in the air. Seeds were planted $15 \mathrm{~cm}$ x $40 \mathrm{~cm}$ spacing, filled with two seeds per hole. The planting holes were covered with organic fertilizer at a dose of 1 ton/ha or about one tablespoon per hole. The sowing time was less than 10 days after harvesting rice. NPK fertilizers were given next to the row of plants when the soil was sufficiently moist and the plants were around 10 days old with a dose of $200 \mathrm{~kg}$ NPK Phonska/ha and 50 kg SP-36/ha.

Weeding was done two times, first one before planting and second one was two weeks after planting by spraying 5 1/ha Gramoxone 276SL herbicide. Vir-Gra 
biological pesticides was overhead sprayed three times during crop growing period $(2 \mathrm{~g} / \mathrm{l}$ water and 48 1/ha suspension in total). Harvesting was done by cutting the stems near the surface of the soil when the plant marked by yellowing and falling leaves, pods filled with brown and dried.

Observation of plant growth was conducted during the vegetative phase, generative phase, and at harvest with observational variables including plant height, number of branches, number of leaves, number of nodus, number of flowers, and number of pods. Data were collected from five plants for each treatment replication. Data obtained were analyzed for variance, if significantly different continued with Duncan's Multiple Range Test (DMRT) at the level of $\alpha=5 \%$ using SAS software program.

\section{RESULTS AND DISCUSSION}

\section{General condition of the experimental site}

The experimental site was farmers' rice fields with paddy-rice cropping patterns, soil pH 6.86 with clay structure. The location was a soybean area for DS I in Central Lombok Regency, and includes in a category of rainfed lowland rice fields. The irrigation process relies on rainfall. The soil condition at the sowing time was suitable for planting soybean, but when the plants grow up to harvest there was no rain, therefore the plants experienced water stress. The experimental site in Pengembur Village of Central Lombok Regency is shown in Fig. 1.

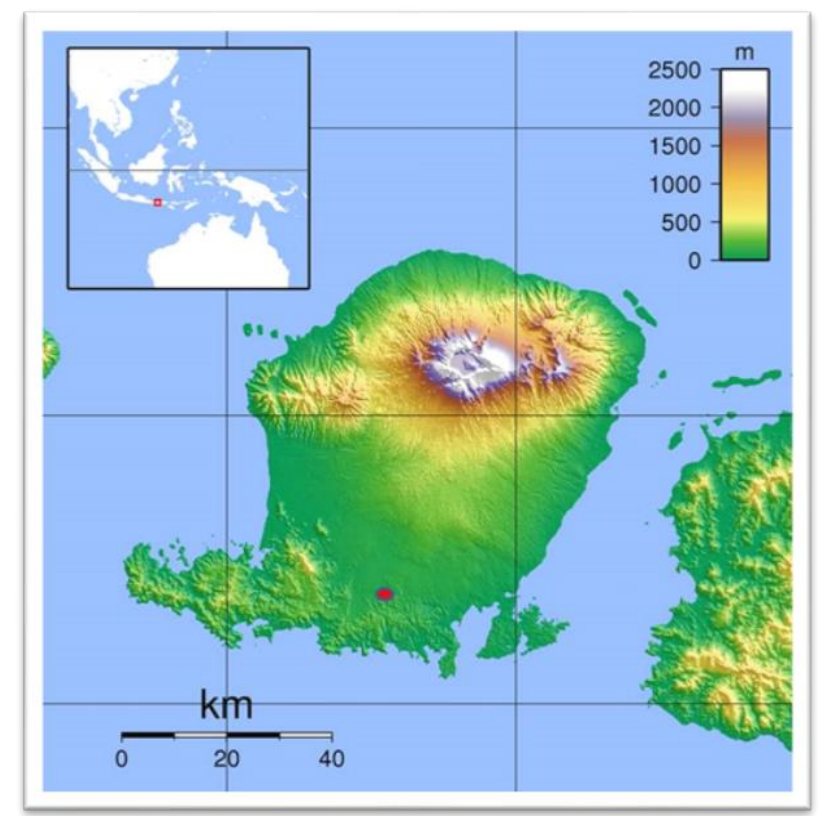

Fig. 1. Map of Lombok Island where the experimental site was in Pengembur Village of Central Lombok Regency with red dot sign at the lower part of the map 


\section{Vegetative phase}

Analysis of variance showed that soybean varieties did not significantly influence the plant height and number of branches where the plant height for Dena 1 variety $(65.6 \mathrm{~cm})$, Argomulyo $(63.9 \mathrm{~cm})$, Burangrang $(59.8 \mathrm{~cm})$, and Dega $1(53.9 \mathrm{~cm})$. In contrast to plant height, the number of branches was produced by the Burangrang variety (2.7) compared to other varieties (1.7). In contrast to plant height and number of branches, soybean varieties have a significant effect on the number of leaves, number of nodus, and number of flowers. The Argomulyo and Burangrang varieties were not significantly different in all parameters. Dega 1 variety was different from Argomulyo variety for all parameters. Whereas the Dena 1 variety differed only from the Argomulyo variety for the parameters of number of leaves and number of flowers (Fig. 2).

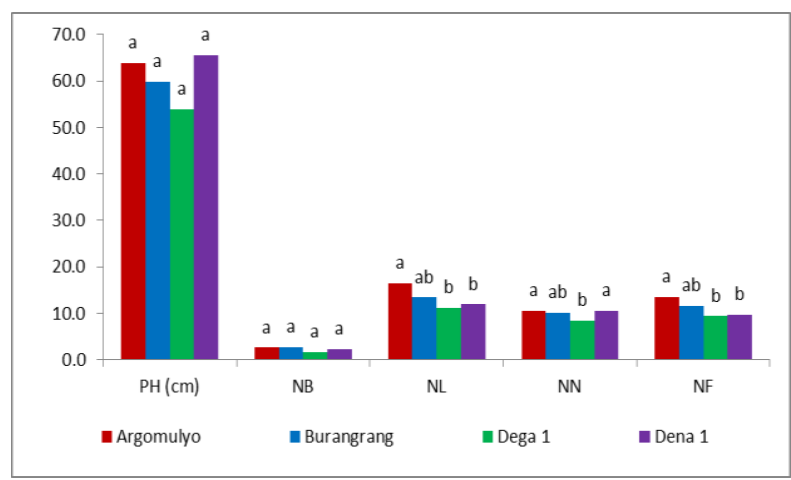

Fig. 2. Agronomic performance of four improved soybean varieties in rainfed lowland of Central Lombok Regency during the vegetative phase where $\mathrm{PH}=$ Plant height, $\mathrm{NB}=$ number of branches, $\mathrm{NL}=$ number of leaves, $\mathrm{NN}=$ number of nodus, and $\mathrm{NF}=$ number of flowers

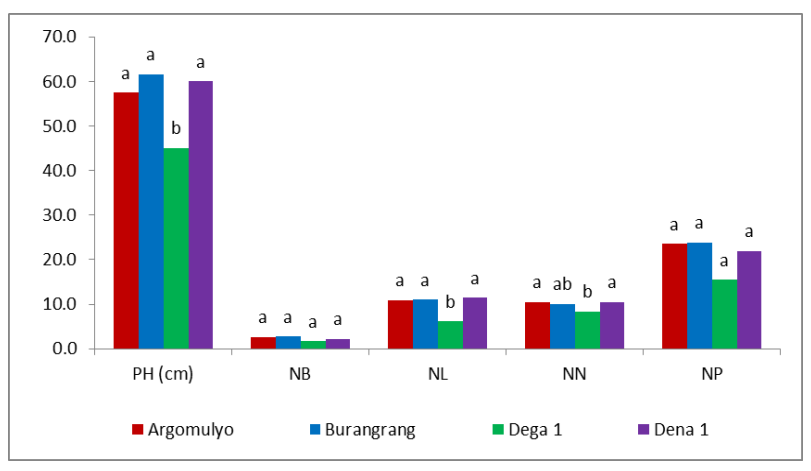

Fig. 3. Agronomic performances of four improved soybean varieties in rainfed lowland of Central Lombok Regency during the generative phase where $\mathrm{PH}=$ plant height, $\mathrm{NB}=$ number of branches, $\mathrm{NL}=$ number of leaves, $\mathrm{NN}=$ number of nodus, and $\mathrm{NP}=$ number of pods 


\section{Generative phase}

Analysis of variance for the generative phase showed that soybean varieties did not have a significant effect on the number of branches and number of pods. The number of branches did not experience an increase from the vegetative phase. As for the number of pods, the Argomulyo and Burangrang varieties have almost the same number of pods (23), while number of pods produced by Dega 1 variety was less than 20 but dit not statistically different (Fig. 3).

\section{Environmental constraints during the experiment}

During the soybean experiment in DS

I 2018, there were an environmental constraint which was facing such as no rainfall during the crop growing. The very limit of rainfall since the beginning of April 2018 when the crop was already growing for about one month and need more water. Data of rainfall during the 2018 soybean research activity can be seen in Fig. 4. The figure shows the comparison of rainfall data in 2017 and 2018. Since April 2018 the rainfall was almost zero compared to April 2017 which was still reached $154 \mathrm{~mm}$. Likewise, in May 2018 there was no rain in the experimental site, while in the same month of the previous year there was still $11 \mathrm{~mm}$ of rainfall.

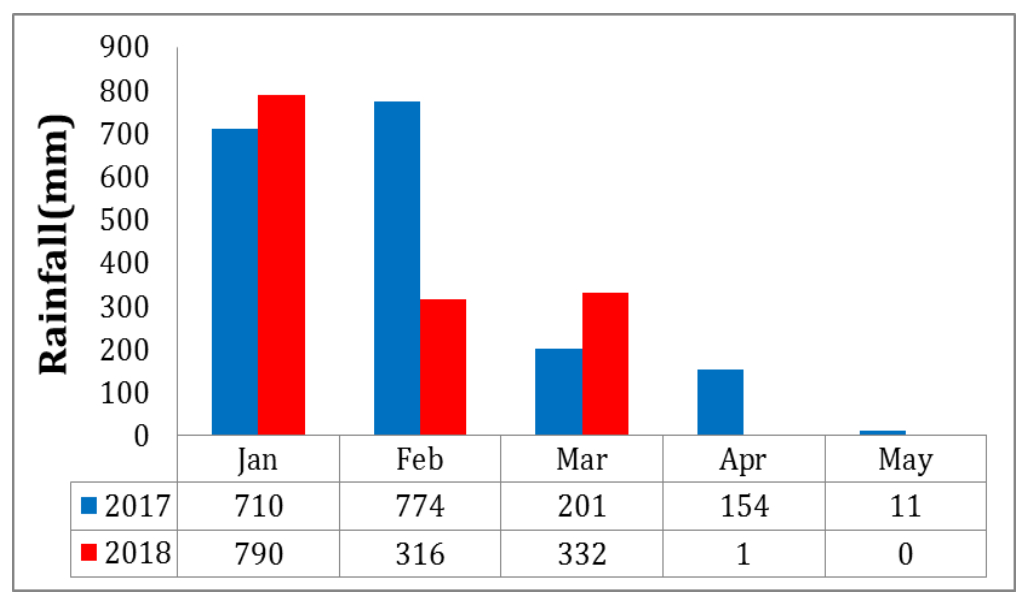

Fig. 4. Rainfall data in Lombok Island during the soybean experiment in rainfed lowland of Central Lombok Regency

\section{Discussion}

The difference in crop performance is due to the adaptability of each variety to environmental conditions. Different genotypes can produce different plant responses even in the same environment. The 
leaf is an important part of the plant because it functions as a place for photosynthesis. The resulting photosynthate will be distributed to other plant parts. In the vegetative phase, photosynthate is widely used for forming plant parts or increasing plant size (Lin et al., 2007).

Dega 1 and Dena 1 soybean varieties are among the soybean improved varieties released by Indonesian Legumes and Tuber Crops Research Institute (ILETRI) in 2015 and 2014 respectively (Balai Penelitian Tanaman Aneka Kacang dan Umbi, 2016). The variety has a more important role than other components in soybean cultivation technology (Lagiman et al., 2015). Climatic conditions in the absence of rain affect crop performance. When compared with the research of Lestari et al. (2015), plant height and number of branches for Argomulyo and Burangrang varieties had lower values. Plant height is an important character because it can affect the number of branches and the number of productive nodus. Research by Pakpahan (2009) shows that there is a significant correlation between plant height and number of branches for soybean varieties Seulawah and Baluran.

Soybean varieties in the generative phase have an effect on parameters plant height, number of leaves, and number of nodus. Plant height was seen to have decreased in all varieties except Burangrang.
Although the Burangrang variety has increased plant height, it was not different from the Argomulyo and Dena 1 varieties. While the Dega 1 variety, besides decreasing plant height, also produces the lowest plant height.

In addition to plant height, reduction also occurs in the number of leaves. This is presumably because the observations were made before the harvest therefore the leaves have fallen because the plants have started to turn yellow and old. The number of leaves is the same as plant height, which is the lowest amount produced by Dega 1 variety and significantly different from other varieties.

The number of nodus in the generative phase did not experience an increase, the same as the number of branches during vegetative phase. During the generative phase the growth of plant parts is not much because the photosynthate produced are widely used for seed formation. When compared with other studies, the performance of soybean plants in rainfed lowland was not optimal. This is caused by no occurrence of rain during the plant growth period until the harvest period. Drought stress causes plants to become shorter and faster to release pods in response to survival. Climate change is causing a shift in seasons. This happened at the experimental site because in the previous years, DS I period was sufficient water availability due to the 
presence of rain. While during the research the rain did not occur during the period of plant growth.

Soybean yields increased over time with fertilizer and mulch application (Qin et al., 2015). In addition, the rain factor has a positive interaction with fertilization for yield parameters in wheat crops (Qin et al., 2015). This shows that a year with relatively high rainfall increased crop yields with fertilizer application. The number of pods is an important component because it can affect the amount of soybean produced. Lestari et al. (2015) showed a higher number of pods for the Argomulyo and Burangrang soybean varieties. Due to dry season occurred earlier in April 2018, yield on Bio-Detas input package was reached $578 \mathrm{~kg} / \mathrm{ha}$ compared to farmer's existing technology was $393 \mathrm{~kg} / \mathrm{ha}$. This yield indicated that climate change in 2018 where the dry season occurred earlier significantly lower the yield on Bio-Detas application package compared to its potential (2.72 tons/ha).

\section{CONCLUSION}

On the basis of the results presented and implications discussed on the application of Bio-detas input package on soybean in rainfed lowland of Central Lombok Regency, the following conclusions are reached (a) Varieties had a significant influence on the number of leaves, number of nodus and number of flowers during the vegetative phase, (b) During the generative phase there were a significant effect of varieties on plant height, number of leaves and number of nodus, (c) Due to dry season occurred earlier in April 2018, yield on Bio-detas input package was reached $578 \mathrm{~kg} / \mathrm{ha}$ compared to farmer's existing technology was $393 \mathrm{~kg} / \mathrm{ha}$, (d) Based on the result from this research, it is recommended that Argomulyo variety is suitable variety for dry land of Central Lombok Regency.

\section{ACKNOWLEDGEMENTS}

We would like to thanks to the Indonesian Agency for Agricultural Research and Development (IAARD) for funding this research. We also would like to thanks Dr. Ir. M. Saleh Mokhtar, MP., Director of Institute for Assessment of Agricultural Technology (IAAT) West Nusa Tenggara Province for his permission to the soybean team to do this research during the financial year of 2018 . Each author contributed equally in preparing and writing this paper.

\section{REFERENCES}

Balai Penelitian Tanaman Aneka Kacang dan Umbi. (2016). Deskripsi Varietas Unggul Aneka Kacang dan Umbi. $8^{\text {th }}$ ed. Malang, Balai Penelitian Tanaman Aneka Kacang dan Umbi, Badan Penelitian dan Pengembangan Pertanian. [In Indonsian]

Badan Pusat Statistik Provinsi Nusa Tenggara Barat. (2018). Luas Lahan 
Menurut Penggunaan Provinsi Nusa Tenggara Barat 2017. Badan Pusat Statistik Provinsi Nusa Tenggara Barat. [In Indonesian]

Basuchaudhuri, P. (2016). Source-sink relationships in soybean. Indian Journal of Plant Sciences. Vol 5(2) 19-25.

Herawati, N., Aisah, AR., Tantawizal, Mujiono, Feriman, Susanti, Y. (2018). Sekolah lapang kedaulatan pangan mendukung swasembada pangan terintegrasi desa mandiri benih komoditas kedelai. Laporan Akhir Tahun, Balai Pengkajian Teknologi Pertanian NTB. [In Indonesian]

Kementerian Perdagangan. (2018). Analisis perkembangan harga bahan pangan pokok di pasar domestik dan internasional. Pusat Pengkajian Perdagangan Dalam Negeri, Badan Pengkajian dan Pengembangan Perdagangan, Kementerian Perdagangan Republik Indonesia. [In Indonesian]

Kementerian Pertanian. (2019). Produksi, luas panen, dan produktivitas palawija di Indonesia 2014-2018. Diunduh 14 Mei 2019 dari http://www.pertanian.go.id/Data5tahun / TPATAP-2017(pdf)/01PalawijaNasional.pdf. [In Indonesian]

Lagiman, Basuki, Rochim, B., dan Wantoro, E. (2015). Keragaan sifat agronomi dan hasil lima genotype kedelai generasi F3 hasil persilangan. Agrivet 19:30-35. [In Indonesian]

Lenin, I., Siska, W., Azmir. (2017). Pengaruh pemupukan terhadap kacang tanah di lahan tadah hujan Sumatera Barat. Jurnal Pengkajian dan Pengembangan Teknologi Pertanian 20(3):209-220. [In Indonesian]

Lestari, R.H.S., Kasim, A., and Kadir, S. (2015). Keragaan Varietas Unggul Baru Kedelai Di Papua. Prosiding Seminar Hasil Penelitian Tanaman Aneka Kacang dan Umbi Tahun 2014, 156-60.
Bogor: Pusat Penelitian dan Pengembangan Tanaman Pangan, Badan Penelitian dan Pengembangan Pertanian. [In Indonesian]

Lin, M.K.H.B., Lee, H.Y., Varkonyi, G.E, Taoki, K.I., Miura, E., Xocostle, C.B., Gendler, K., Jorgensen, R.A., Phinney, B., Lough, T.J., and Lucas, W.J. (2007). Flowering locus protein may act as the long distanceflorigenic signal in the cucurbits. Plant Physiol. 132:11861195.

Pakpahan, G.T. (2009). Evaluasi Karakter Agronomi Beberapa Varietas Kedelai (Glycine max L.). Universitas Sumatera Utara. http://repository.usu.ac.id/bitstream/ handle/123456789/7688/09E00956.pdf;seq uence $=1$. Downloaded on 6 June 2018 . [In Indonesian]

Qin, W., Wang, D., Guo, X., Yang, T., and Oenema, O. (2015). Productivity and sustainability of rainfed wheat-soybean system in the North China Plain: result from a long-term experiment and crop modelling. Scientific Report 5: 1-16.

Zakaria, A.K. (2010). Program pengembangan agribisnis kedelai dalam peningkatan produksi dan pendapatan petani. Jurnal Litbang Pertanian 29(4):143-153. [In Indonesian] 